\title{
Improving Students' Creative Thinking Skill in Mathematics through PBL Based on Catur Pramana by Controlling Students' Numeric Skill
}

\author{
*I Made Ego Teja Buana1, I Gede Astawan², I Gusti Ngurah Japa ${ }^{3}$ \\ 123 Program Studi Pendidikan Guru Sekolah Dasar, Universitas Pendidikan Ganesha, Singaraja, Indonesia
}

\author{
A R T I C L E I N F O \\ Article history: \\ 1 Mei 2020 Received in \\ revised form \\ 11 Juni 2020 \\ Accepted 10 Juli 2020 \\ Available online 25 Agustus \\ 2020 \\ Kata Kunci: \\ PBL, catur pramana, \\ berpikir kritis, \\ Keywords: \\ PBL, catur pramana, critical \\ thinking
}

\begin{abstract}
A B S T R A K
Rendahnya keterampilan berpikir kritis Matematika siswa dalam mengikuti pembelajaran menjadi masalah utama dalam penelitian ini. Hal tersebut disebabkan oleh model pembelajaran yang digunakan tidak tepat dan kurang bervariasi. Penelitian ini bertujuan untuk menganalisis pengaruh model Problem Based Learning (PBL) berlandaskan Catur Pramana terhadap keterampilan berpikir kritis Matematika dengan mengontrol kemampuan numerik. Penelitian ini adalah quasi eksperimen, dengan desain Posstest Only Control Group Design. Populasi dalam penelitian ini adalah seluruh kelas V SD dengan jumlah 177 orang siswa. Metode pengumpulan data dilakukan menggunakan tes pilihan ganda dan tes esai. Data yang diperoleh dianalisis menggunakan uji ANAKOVA (analisis kovarian) dengan bantuan SPSS 20.0 for windows. Hasil dari penelitian ini adalah, terdapat pengaruh yang signifikan Model Problem Based Learning (PBL) berlandaskan
\end{abstract} Catur Pramana terhadap keterampilan berpikir kritis Matematika dengan diperoleh F hitung 29,219 dengan sig; $=0,000<0,05$, terdapat pengaruh yang signifikan Model Problem Based Learning (PBL) berlandaskan Catur Pramana terhadap keterampilan berpikir kritis Matematika setelah mengontrol kemampuan numerik siswa diperoleh Fhitung 9,398 dengan sig. $=0,004<0,05$; dan terdapat kontribusi yang signifikan kemampuan numerik terhadap keterampilan berpikir kritis Matematika sebesar 35,05\%. Berdasarkan temuan-temuan tersebut, dapat disimpulkan bahwa Model Problem Based Learning berlandaskan Catur Pramana berpengaruh positif serta terdapat kontribsi kemampuan numerik terhadap keterampilan berpikir kritis Matematika siswa.

\section{A B S T R A C T}

The Low Learning Thinking of students in learning Mathematics becomes a major problem in this research. This is caused by the learning model used which is incorrect and less varied. This study analyzed the influence of Problem Based Learning (PBL) models based on Catur Pramana on critical thinking skills with numerical ability control. This research was a quasi-experimental, with Posttest Only Control Group Design. The population in this study were all fifth-grade elementary schools with 177 students. The data collection method was done by using multiple-choice tests and essay tests. The data obtained were analyzed using the ANAKOVA test (covariance analysis) with the help of SPSS 20.0 for windows. The results of this study are significant results of the Problem Based Learning Model (PBL) based on Catur Pramana on critical thinking skills with Fcount 29,219 with sig; $=0,000$ $<0.05$, there is a significant effect of Problem Based Learning (PBL) model based on Catur Pramana on mathematical thinking skills after obtaining numerical ability of students who obtain Fcount 9,398 with sig. $=0.004<0.05$; and are considered significant who have numerical ability to critical thinking skills of $35.05 \%$. Based on these findings, it can be concluded that the Problem Based Learning Model based on Catur Pramana proves positive and there is a contribution of numerical ability to the critical thinking ability of Mathematics students.

Copyright (C) Universitas Pendidikan Ganesha. All rights reserved

Corresponding author

E-mail addresses: tejabuana423@gmail.com (Teja) ${ }^{1}$, igedeastawan@yahoo.com (Astawan)22, igustingurah.japa@undiksha.ac.id (Japa) ${ }^{3}$ 


\section{Introduction}

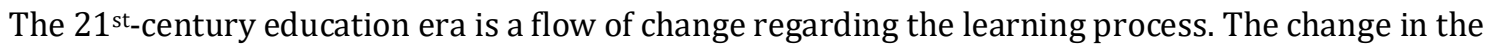
education system in the $21^{\text {st }}$ century is an important thing to be concerned about. Every single change happens always adapt to the times. Indonesian curriculum has been changed into the 2013 curriculum. On the curriculum 2013, the roles of students and teachers are important to support the learning process. The use of strategy in the learning process is needed in supporting the realization of all competencies in the curriculum (Sukma \& Ibrahim, 2016; Fauziah et al., 2018). Apart from developing learning strategies, the teacher also has an important role in the learning process, namely as a facilitator. Therefore, teachers must be able to adapt to change, so that education can continue to develop and educational goals can be achieved, so that the goals of the 2013 curriculum can be achieved. The designation of K13 for this period also shows characteristics that conform to the 21st Century. Special characteristics possessed by 21stcentury learning, namely, students become a learning center (student-centered), able to develop student creativity, can create an interesting, meaningful and pleasant atmosphere, are able to develop abilities that are filled with meaning and value, students actively act, emphasizes more on exploring, discovering, and creating and being able to produce a lesson with real situations and actual contexts (Afandi et al., 2019; Fauziah et al., 2018). Based on those characteristics, students are emphasized and assisted with adequate skills. The skills needed by the students in the $21^{\text {st }}$ century are Communication, Collaboration, Critical thinking and problem solving, and Creativity and Innovation. One of those skills is thinking critically. Thinking critically is a process of composing logical insight which is focusing on the need of deciding as to what it is believed and to be done (Abadi et al., 2020; Pursitasari et al., 2020; Mutakinati et al., 2018). Other than that, Walker (Redhana, 2013) explains that thinking critically is a creative process that can drive the students to get new knowledge bypassing several problem solving and collaboration. Meanwhile, thinking critically is included in the process of thinking carefully thus it can help someone to create, evaluate, and make decisions on what is believed and done (Cáceres et al., 2020; Hamdu et al., 2020) . In a nutshell, thinking critically is a skill of knowledge process and skills that are used to solve the appearing problems, make decisions, and analyze any other possibilities and do research from the gained data and information, so that it produces information and conclusion that are wanted. The skill has a strong correlation with Mathematics.

But there are still many teachers who have not been able to implement the 2013 curriculum in the learning process properly, especially in Mathematics. Teachers are still not ready to implement the 2013 curriculum (Cáceres et al., 2020; Hamdu et al., 2020). Based on the observation result that was done in elementary schools (SD) at Gugus VI Sukasada Sub-district, it is concluded that there are several problems which are there is a lack of students' ability and there is still lack of students' willingness in learning Math. In addition, the findings in the field show that there is a lack of variation and innovation in the models used in teaching and learning activities. So that the lack of skills of students towards critical thinking. Problems in mathematics, are caused based on how the teacher teaches, it does not reflect innovation (Astuti et al., 2013). Meanwhile, the value in learning obtained by students was less than desired. Based on the results of the mid-semester assessment for 177 students, it shows that the percentage of students who obtained learning outcomes above the KKM (a passing grade) was $44 \%$ while the percentage of students who obtained learning outcomes below the KKM was $56 \%$. This finding was reinforced by the results of interviews with grade $\mathrm{V}$ teachers who stated that it was still difficult to condition the class in learning Mathematics. In addition, the abilities or talents of each student can affect understanding and the learning process. So that mathematics learning in class is not going well. Based on the results of observations and interviews conducted with teachers, efforts are needed to anticipate and improve the learning process in a better direction. The role of the teacher is very visible in every learning process. In addition to teachers being able to master teaching materials or teaching materials, teachers must also know how the material is delivered.

So far, many studies have focused on improving students' critical thinking. Some of them are research conducted by (Kumullah et al., 2018) which shows that the PBL learning model can improve students' critical thinking skills. Research conducted by (Ningsih et al., 2018) states that using the PBL learning model can improve students' thinking skills. Based on the research that has been done, improving students' critical thinking skills can be done by applying models that can increase the active role of students during learning to explore and construct the knowledge they get and to solve the problems they get. For classroom learning to be effective, innovation is needed in learning to be able to make learning meaningful. One learning model that can be applied is problem-based learning (PBL). PBL is an innovative model that makes students the center of this learning. The PBL model helps students to practice thinking 
to solve a problem (Prasedari et al., 2019; Mutakinati et al., 2018; Abdullah et al., 2015). PBL is characterized by learning by starting with posing a problem, then solving the problem (Suryawati et al., 2020; Wibawa \& Winarsih, 2020). (Effendi \& Hendriyani, 2020; Pamungkas et al., 2019) stated that PBL is an innovation in learning based on a belief by making a problem for the center on the acquisition and integration of the latest understanding. This learning innovation makes students the main center of learning activities; it will place students alive in the learning process. PBL's innovative aim is to be able to improve students 'logical thinking skills, including the skills to analyze situations, implement the intelligence they have based on the latest conditions, recognize the discrepancy of facts, opinions and develop students' ability to create arguments objectively, and work together to solve a problem (Effendi \& Hendriyani, 2020; Kumullah et al., 2018)

In this study, to obtain maximum results, the PBL learning model was modified base d on the Hindu concept, namely Catur Pramana. PBL can be combined with local wisdom, one of which is Catur Pramana. Catur Pramana is a learning cycle using the values of local wisdom teachings, namely pratyaksa (observing), anumana (concluding), upamana (comparing), sabda (testimony). (Kerti, 2018; Setyawan et al., 2017). Based on the concept, it can be concluded that the Catur Pramana concept can be implemented with the problem-based learning (PBL). To discuss the PBL and Catur Pramana learning models, the objectives of this study were formulated, namely to analyze the significant effect of the problem-based learning (PBL) learning model based on Catur Pramana on critical thinking skills of mathematics by controlling numerical abilities. The PBL learning model based on Catur Pramana later students can discuss with their groups to find solutions to the problems that have been given by thinking well and expressing their opinions. The PBL learning model based on Catur Pramana is a system of delivering learning material based on Catur Pramana to develop students' critical thinking skills. This can make learning fun, foster self-confidence, and affect the critical thinking skills of grade $\mathrm{V}$ students.

This argument is supported by the research carried out by (Haryati, 2017) which states that the PBL learning model increases the ability of students' critical thinking. Which states that the PBL learning model can improve students' critical thinking skills. This statement is in tune with (Ningsih et al., 2018) which states that using the PBL learning model can improve students' thinking skills. Because, the average value of students' critical thinking skills during pre-action was $63.49 \%$, which was an increase in cycle II to $76.98 \%$, in cycle III to $84.12 \%$. Based on the research that has been carried out, the research conducted has differences with previous research conducted, the difference is seen from the material used and the research variables. The choice of the PBL model is adjusted to the characteristics of students. In applying the PBL learning model the teacher implements Catur Pramana by observing (Pratyaksa), concluding (Anumana), comparing (Upamana), and testimony (Sabda) (Damanik, 2019). With local wisdom, it is hoped that the model used can be more attractive and effective. In addition to innovative learning, being able to measure students' logical thinking skills can be done by controlling the numerical skills of students themselves. The purpose of this study was to analyze students 'critical thinking mathematics skills through the PBL model based on Catur Pramana by controlling students' numerical abilities.

\section{Method}

The research carried out was experimental research. This type of experimental research used is a quasi-experiment. The experimental design used in this study was "Posttest Only Control Group Design" (Sugiyono, 2016). In this research design, students were given treatment within a certain period, then a posttest test was conducted at the end of the lesson. There were three stages in the research, namely the preparation stage, the implementation stage, and the final stage. This research was conducted in the elementary school of Cluster VI Sukasada Sub-district for the 2019/2020 school year for approximately seven months from May to April. The research population was all class V SDN Gugus VI Sukasada district for the 2019/2020 academic year, there were 8 classes from 7 elementary schools with a total of 177 students. "Sampling is done to determine a portion of the population to be the object of research, it must be appropriate to consider representation based on the population basis, to obtain data and things needed", (Indrawan \& Yaniawati, 2016:93). The sample had a large number of 46 students, the experimental class was all grade 5 students of Panji Anom 2 elementary school with 23 students and the control class was all grade 5 students of 4 Panji Anom elementary schools with 23 students.

The use of techniques to obtain the required sample uses random sampling. The number of samples was 46 students, the experimental group was all students in grade V SDN 2 Panji Anom with a total of 23 students and the control group namely all students in grade V SDN 4 Panji Anom with a total of 23 students. Data on students' higher thinking skills were collected through an essay instrument that had 10 points. The 10 questions referred to the indicators of logical thinking skills and mathematics material for grade 5 elementary schools. Indicators of logical thinking skills namely, students can respond to 
explanations, students can provide conclusions and improve basic skills. Meanwhile, data on students' numerical abilities were collected using a multiple-choice test instrument with a lot of questions, namely 23 items. Of the 23 questions, they referred to indicators, namely: number subtraction, number addition, number division, multiplication of numbers, dexterity in calculating exponents, and accuracy in calculating percentages. The following is a numerical ability test grid.

Table 1. Numerical Ability Test Grid

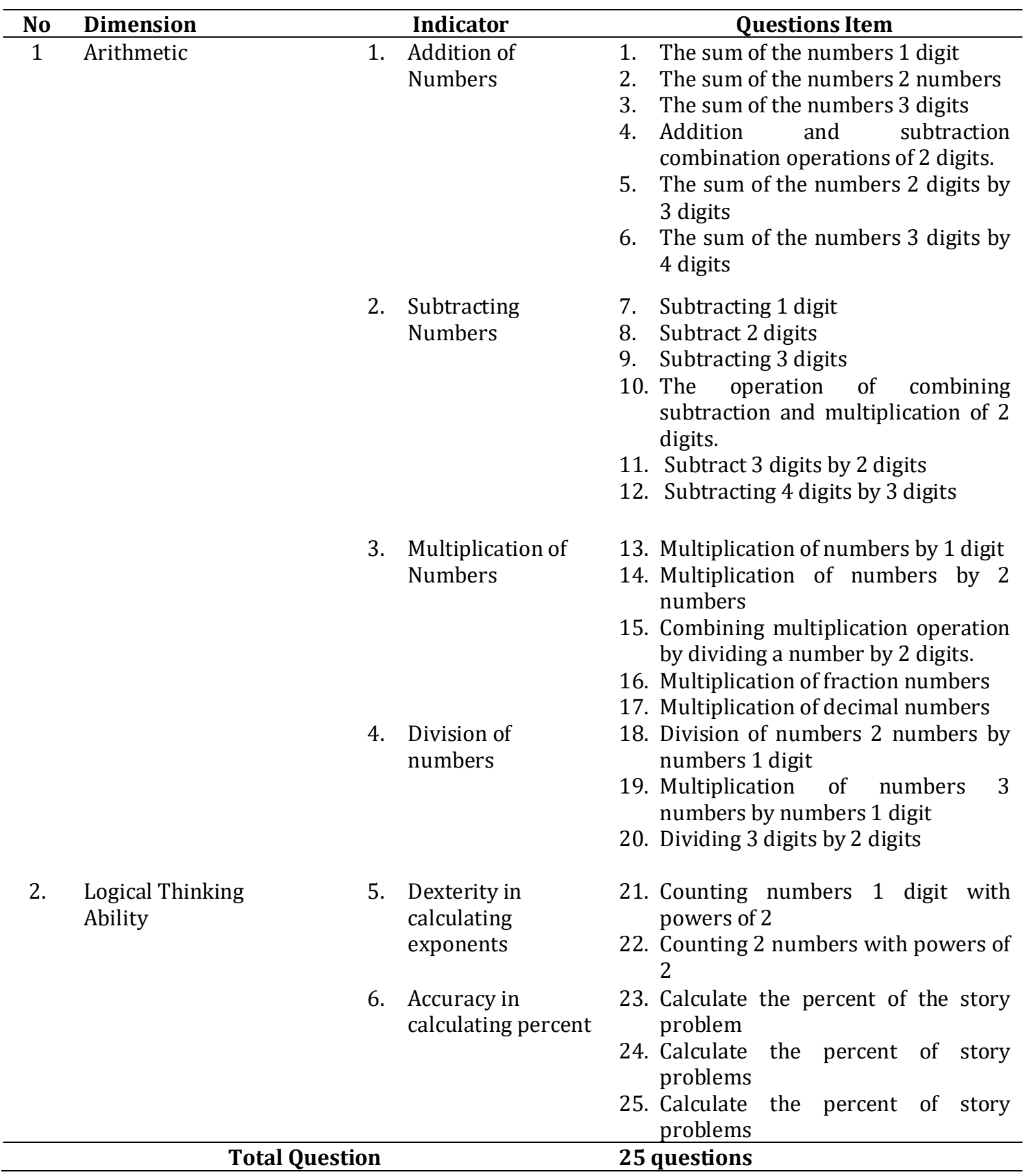

This research was analyzed using, descriptive and inferential analysis. The prerequisite tests carried out were the data distribution normality test, the variance homogeneity test, and the linearity test. The data distribution normality test aimed to ensure that the sample is normally distributed, so that hypothesis testing could be carried out. The data that was tested for normality were data on the experimental group mathematical logical thinking skills, the control group mathematical logical thinking skills data, and the students; numerical skills data. Homogeneity testing was carried out when the data 
were in a normal distribution. Homogeneity testing to show the inequality obtained from hypothesis testing. Furthermore, hypothesis testing was needed. The first hypothesis was tested using one-way ANOVA, the second hypothesis was tested using one-way covariance (ANAKOVA) and the third hypothesis was tested using product moment alignment. In the research, the data were analyzed using the help of SPSS Statistics 20.0 for windows at the $5 \%$ significance level.

\section{Result and Discussion}

The data contained in the mathematics critical thinking ability of students using PBL learning based on Catur Pramana and students without PBL learning based on Catur Pramana and student numerical ability data. All data obtained were described from the data tendency, namely, mean, median, mode, standard deviation, variance, range, maximum, and minimum. The results of the data tendency calculation are presented in Table 2.

Table 2. Recapitulation of Research Data Tendency

\begin{tabular}{lccc}
\hline & $\begin{array}{c}\text { Numeric } \\
\text { Ability }\end{array}$ & $\begin{array}{c}\text { Mathematical Critical } \\
\text { Thinking Skills Control Class }\end{array}$ & $\begin{array}{c}\text { Mathematical Critical Thinking } \\
\text { Skills Experiment Class }\end{array}$ \\
\hline Mean & 18,43 & 29,52 & 39,04 \\
Standard & 3,32 & 5,79 & 7,45 \\
Deviation & & & \\
Variants & 11,07 & 33,62 & 55,58 \\
Range & 11,00 & 21,00 & 25,00 \\
Maximum & 23,00 & 40,00 & 48,00 \\
Minimum & 12,00 & 19,00 & 25,00 \\
\hline
\end{tabular}

Based on the data from the recapitulation results in Table 1 shows that the results of the mathematics critical thinking skills of the experimental group students who were taught using the Problem Based Learning model based on Catur Pramana, were greater than the results of the control group students' critical thinking mathematics skills who were not taught using the Problem model. Based Learning based on Catur Pramana. Furthermore, hypothesis testing was, hypothesis testing was carried out to determine the influence of the model applied. Before hypothesis testing could be done, it was necessary to first test the prerequisites for data analysis, namely, normality test, homogeneity test of variance, and linearity test. Based on the prerequisite test that had been carried out, the data for the critical thinking skills of students in the experimental group, the control group, and the numerical abilities of students in the normal distribution were obtained. Data from students' critical thinking mathematics skills in the experimental group and the control group both had homogeneous variants. The variables of mathematical thinking skills and the covariable of numerical ability were linear and the coefficient of the regression direction means.

Testing the normality of data distribution using the Kolmogorov-Smirnov and Shapiro-Wilk techniques at a significant level of 5\% with the help of SPSS 20.0 for windows. In the Kolmogorov-Smirnov statistics, the statistical value in the experimental group was $F=0.132$ with a significance number of $0.200>0.05$, the statistical value in the control group was $F=0.163$ with a significance value of $0.117>$ 0.05 and the statistical value in the covariable $F=0.13$ with the significance level was $0.200>0.05$. Whereas in the Shapiro-Wilk statistic, the statistical value in the experimental group was $\mathrm{F}=0.920$ with a significance level of $0.066>0.05$, the statistical value in the control group $\mathrm{F}=0.9 .57$ with a significance value of $0.407>0.05$ and a statistical value on the covariable $F=0.9392$ with a significance number $0.169>$ 0.05. Therefore, the data for students' critical thinking mathematics skills that were taught using the Problem Based Learning model based on Catur Pramana, the mathematics critical thinking skills of students who were not taught with the Problem Based Learning model based on Catur Pramana and the numerical abilities of students were normally distributed.

Homogeneity of variance was tested using Levene's Test of Error Variances technique. The distribution is classified as homogeneous if sig> 0.05 . The sig setting is 0.118 , it shows that the result is significantly higher than 0.05 . Therefore, the results obtained are described. Thus, it can be gained from the critical thinking skills of mathematics of students who were in the experimental class and the data of critical thinking skills of students in the control class, both of which have homogeneous variants. Testing for linearity and meaning of the regression direction was carried out using the SPSS application. 20.0 For windows. The provisions for linearity testing are if the significant deviation of linearity is $>0.05$ so that the data is linear, and otherwise the data is not linear. The criteria in testing the meaning of regre ssion if the 
significance of the linearity is $<0.05$, the regression direction coefficient is meaningful; otherwise, the regression direction coefficient is meaningless. The deviation significance value of linearity is 0.225 , so the variable of mathematical thinking skills and the covariable of numerical ability is linear. Whereas in the regression significance test, it shows the significance values for linearity, namely $0.032<0.05$, so the regression coefficient is significant. It can be seen that the deviation significance value of linearity is 0.218 , so the variables of Mathematical thinking skills and the covariable of numerical abilities are linear. Whereas in the regression significance test, it shows the significance values of linearity, namely 0.029 $<0.05$, so the regression coefficient is significant. Based on the results of prerequisite testing, the data includes testing for normality, homogeneity of variance, and linearity. It can be concluded that the data can be used in hypothesis testing. The results of the calculation of hypothesis 1 using one-way ANOVA assisted by using the application of SPSS 20.0 for windows can be seen in Table 3 .

Table 3. Hypothesis Results of One Way Anova Data

\begin{tabular}{lccccc}
\hline & Sum of Squares & df & Mean Square & F & Sig. \\
\hline Between Groups & 1755,159 & 16 & 109,697 & 2,545 &, 014 \\
Within Groups & 1250,167 & 29 & 43,109 & & \\
\hline Total & 3005,326 & 45 & & & \\
\hline
\end{tabular}

After analyzing the data, it was obtained F-count 2.545 with sig0.014 $<0.05$. Therefore, Ho was not accepted and Ha was accepted. So, it can be concluded that there is indeed a considerable difference in the critical thinking skills of students who are taught using the BL model based on Catur Pramana, students who are not taught PBL based on Catur Pramana. After that will be followed up on the value. The results of calculating hypothesis 2 using one-way covariance analysis assisted by using the application of SPSS 20.0 for windows can be seen in Table 4 .

Table 4. Hypothesis Data Results Using ANAKOVA

\begin{tabular}{lccccc}
\hline \multicolumn{1}{c}{ Source } & Type III Sum of Squares & df & Mean Square & F & Sig. \\
\hline Corrected Model & $1386,237 a$ & 2 & 693,118 & 18,408 &, 000 \\
Intercept & 1166,183 & 1 & 1166,183 & 30,972 &, 000 \\
X & 343,606 & 1 & 343,606 & 9,128 &, 004 \\
K & 254,275 & 1 & 254,275 & 6,753 &, 013 \\
Error & 1619,090 & 43 & 37,653 & & \\
\hline Total & 570609,000 & 46 & & & \\
Corrected Total & 3005,326 & 45 & & & \\
\hline
\end{tabular}

After analyzing the data, it was obtained an F-count of 6.753 with sig $0.013<0.05$. So, Ho was not accepted and Ha was accepted. So that it can be concluded that there is indeed a big difference in the critical thinking skills of Mathematics of students who are taught using the PBL model based on Catur Pramana without learning the PBL model based on Catur Pramana after the numerical ability covariables are controlled. The results of calculating hypothesis 3 using product-moment correlation with the help of using the application of SPSS 20.0 for windows can be seen in Table 5.

Table 5. Hypothesis Testing Results Contribution of Numerical Ability to Mathematical Critical Thinking Skills

\begin{tabular}{llcc}
\hline & & Think Critically & Numeric \\
\hline \multirow{2}{*}{ Think } & Pearson Correlation & 1 &, $614^{* *}$ \\
Critically & Sig. (2-tailed) & &, 000 \\
& $\mathrm{~N}$ & 46 & 46 \\
\multirow{5}{*}{ Numeric } & Pearson Correlation &, $614^{* *}$ & 1 \\
& Sig. (2-tailed) &, 000 & 46 \\
\hline
\end{tabular}

Based on Table 4, it is obtained that the value of the Pearson coefficient is $r$-count $=0.614$. Therefore, it is concluded that Ho is not accepted and Ha is accepted, which indicates that there is a large contribution between the numerical ability co-variables on students' critical thinking skills in mathematics. From the results of positive relationship testing on Person Correlation, this shows that the 
high level of numerical abilities of students will also be the higher of students' critical thinking. The amount of contribution is the square of $r$-count $=0.614$, which is 0.2314 or $37.69 \%$. The first finding, regarding the data analysis of critical thinking skills in Mathematics, is that there is an effect of students' critical thinking mathematics skills who were taught using PBL models based on Catur Pramana with students who are not taught using PBL models based on Catur Pramana. The PBL model based on Catur Pramana is more about how students solve and find solutions to problems given to students related to the subject matter. The PBL model is a learning model that provides training to students with real-world problems as a medium for students to learn critical thinking and problem-solving skills and gain knowledge (Effendi \& Hendriyani, 2020; Mutakinati et al., 2018). The PBL model is expected to be able to implement the concept of Catur Pramana, namely, being able to observe a given problem (pratyaksa), able to provide reasoning related to problems given by the teacher (anumana pramana), able to compare opinions with other friends (upamana pramana). and able to obtain testimony from the results of observations and discussions (Sabda Pramana). So that the existence of an innovative learning model such as the PBL model based on Catur Pramana, will greatly help students in the learning process. Students will become more active because students find, explore, and solve problems given. This is inseparable from the parts of the Catur Pramana that are used in this study. The steps of Catur Pramana include pratyaksa (observing), anumana (concluding), upamana (comparing), sabda (testimony) (Kerti, 2018; Setyawan et al., 2017). The finding is supported by (Primayanti et al., 2019) which shows that there is a significant effect of the PBL model containing local wisdom on the achievement of students' critical thinking skills. Then the research conducted by (Kumullah et al., 2018) which states that the ability to think and understand science concepts of students who apply the PBL model is higher than those taught by the conventional model. These findings are also supported by research (Setyawan et al., 2017) which states that the Catur Pramana-based Quantum Teaching-learning model affects the competency of the science knowledge of class V students of the East Denpasar Srikandi Gugus in the 2016/2017 academic year.

The second finding, regarding the data analysis critical thinking skills of mathematics by controlling numerical abilities, learners are taught using PBL models based on Catur Pramana by controlling numerical abilities. Numerical ability is an understanding of the functions of mathematical operations in the calculation process as well as the accuracy and accuracy in answering a mathematical arithmetic operation problem (Dudung, 2017; Irawaan, 2014). This is also inseparable from the numerical ability test given which relates to numbers. Numerical skills can not only help students in counting numbers but also help students think critically. Therefore, students' critical thinking skills can be improved by giving numerical tests. These findings are corroborated by research conducted by (Dudung, 2017) which states that the learning outcomes of the group of students who have high numerical abilities with problem-based learning are higher than the group of students with project-based learning. Besides, the findings of this study were also strengthened by research conducted by (Irawaan, 2014) which states that there is a direct influence of numerical intelligence on the ability to think critically in mathematics, there is a direct effect of numerical intelligence on the ability to think in mathematics criticism.

The third finding, regarding the contribution of controlling students' numerical talents to critical thinking skills in Mathematics, students were taught using PBL models based on Catur Pramana without learning using PBL models based on Catur Pramana. This significant influence occurs because all students are allowed to think critically in solving problems in the form of an essay test. As expressed by (Damanik, 2019) Catur Pramana by observing (Pratyaksa), concluding (Anumana), comparing (Upamana), and testimony (Sabda) can foster students' critical thinking skills. Giving the Catur Pramana concept will allow students to think critically during the learning process. Catur Pramana encourages students to improve their thinking skills. Especially in solving a problem, and the skills to think logically so that it can improve students' numerical skills. Numerical skills are needed in learning mathematics because it is a basic ability that involves the operations of addition, subtraction, multiplication, and division of numbers so that this numerical ability can support students in solving math problems (Andika et al., 2017). Through numerical abilities, students' critical thinking skills will also improve. This is reinforced by research conducted by (Andika et al., 2017) which states that there is a great influence from numerical skills to critical thinking skills. Based on similar research, it can be concluded that the PBL learning model has a positive impact on students 'critical thinking skills so that it can be used to improve students' critical thinking skills. Based on the explanation of the research results and previous descriptions, it is concluded that there is a significant effect of the PBL learning model based on Catur Pramana on the critical thinking skills of grade V students of SDN Gugus VI, Sukasada District, 2019/2020 academic year. The PBL learning model based on Catur Pramana is suitable to be applied in the learning process as an effort to improve students 'critical thinking skills and can be a reference for teachers when learning in optimizing students' critical thinking skills. 


\section{Conclusions}

Based on the presentation of the findings and the results obtained and the discussion, it is concluded that there is a significant effect of the PBL Model based on Catur Pramana on students' Mathematical critical thinking skills, there is a significant effect of the PBL Model Based on Catur Pramana on students' Mathematical critical thinking skills after controlling the students' numerical abilities and There is a significant contribution of numerical abilities to students' critical thinking skills in Mathematics.

\section{References}

Abdullah, D. I., Z, M., \& H, S. (2015). Keefektifan model pembelajaran problem based learning bernuansa etnomatematika terhadap kemampuan pemecahan masalah siswa kelas VIII. Unnes Journal of Mathematics Education., 4(3). https://doi.org/10.15294/ujme.v4i3.9056

Afandi, Sajidan, Akhyar, M., \& Suryani, N. (2019). Development frameworks of the Indonesian partnership 21 st -century skills standards for prospective science teachers: A Delphi study. Jurnal Pendidikan IPA Indonesia, 8(1), 89-100. https://doi.org/10.15294/jpii.v8i1.11647

Agung, A. A. G. (2014). Buku Ajar Metodologi Penelitian Pendidikan. Aditya Media Publishing.

Ali-Abadi, T., Babamohamadi, H., \& Nobahar, M. (2020). Critical thinking skills in intensive care and medical-surgical nurses and their explaining factors. Nurse Education in Practice, 45(March), 102783. https://doi.org/10.1016/j.nepr.2020.102783

Andika, I. G. A. A., Dantes, N., \& Parmiti, D. P. (2017). Pengaruh pendekatan kontekstual berbantuan media kovariabel kemampuan numerik pada siswa kelas IV. E-Journal PGSD Universitas Pendidikan Ganesha, 5(2), 1-10. https://doi.org/http://dx.doi.org/10.23887/jjpgsd.v5i2.10897

Astuti, I. A. K., Marhaeni, A. A. I. N., \& Sariyasa. (2013). Pengaruh Pendekatan Matematika Realistik terhadap Prestasi Belajar Matematika ditinjau dari Kemampuan Numerik. E-Journal Program Pascasarjana Universitas Pendidikan Ganesha, 3(3), https://www.neliti.com/publications/119523/pengaruh-pendekatan-matematika-realistikterhadap-prestasi-belajar-matematika-di

Cáceres, M., Nussbaum, M., \& Ortiz, J. (2020). Integrating critical thinking into the classroom: a teacher's perspective. Thinking Skills and Creativity, 100674. https://doi.org/10.1016/j.tsc.2020.100674

Damanik, N. (2019). Relasi akal dan agama dalam filsafat Hindu. Jurnal Ushuluddin, 18(1). http://jurnal.uinsu.ac.id/index.php/ushuluddin/article/view/5719

Dudung, A. (2017). Pengaruh model pembelajaran dan kemampuan numerik terhadap hasil belajar permesinan dengan mengontrol potensi keteknikan. Jurnal Teknologi Pendidikan, 19(3). https://doi.org/https://doi.org/10.21009/JTP1903.1

Effendi, H., \& Hendriyani, Y. (2020). The Conceptual and Hypothetical Model of Interactive Blended Problem Based Learning. JPI (Jurnal Pendidikan Indonesia), 8(2), 285. https://doi.org/10.23887/jpi-undiksha.v8i2.24162

Fauziah, A. N. M., Purnomo, A. R., \& Fathonah, N. (2018). The use of a monopoly-like game (MLG) to promote qualified scores for three students competencies. Jurnal Pendidikan IPA Indonesia, 7(3), 280-285. https://doi.org/10.15294/jpii.v6i2.8183

Hamdu, G., Fuadi, F. N., Yulianto, A., \& Akhirani, Y. S. (2020). Items Quality Analysis Using Rasch Model To Measure Elementary School Students' Critical Thinking Skill On Stem Learning. JPI Uurnal Pendidikan Indonesia), 9(1), 61. https://doi.org/10.23887/jpi-undiksha.v9i1.20884

Haryati, Y. (2017). Model Problem Based Learning Membangun Kemampuan Berpikir Kritis Siswa Sekolah Dasar. Jurnal Cakrawala Pendas, 3(2), 57-63. http://dx.doi.org/10.31949/jcp.v3i2.596

Indrawan, R., \& Yaniawati, P. (2016). Metodologi Penelitian. PT. Refika Aditama.

Irawaan, A. (2014). Pengaruh kecerdasan numerik dan penguasaan kKonsep Matematika terhadap kemampuan berpikir kritik Matematika. Formatif: Jurnal Ilmiah Pendidikan MIPA, 4(1), 46-55. https://doi.org/10.30998/formatif.v4i1.138

Kerti, N. N. (2018). Penerapan Catur Pramana sebagai metode ilmiah dalam peningkatakan mutu 
pembelajaran agama Hindu. Jurnal Penjaminan Mutu, 4(1). https://doi.org/http://dx.doi.org/10.25078/jpm.v4i1.401

Kumullah, R., Djatmika, E. T., \& Lia, Y. (2018). Kemampuan berpikir kritis dan penguasaan konsep siswa dengan problem based learning pada materi sifat cahaya". Teori, Pnelitian Dan Pengembangan, 3(2014), 1583-1586. http://dx.doi.org/10.17977/jptpp.v3i12.11798

Mulyadin, M. (2016). Implementasi kebijakan pembelajaran tematik terpadu Kurikulum 2013 di SDN Kauman 1 Malang dan SD Muhammadiyah 1 Malang. Jurnal Edutama, 3(2), 31-48. http://ejurnal.ikippgribojonegoro.ac.id/index.php/JPE/article/view/35/35

Mutakinati, L., Anwari, I., \& Yoshisuke, K. (2018). Analysis of students' critical thinking skills of middle school through stem education project-based learning. Jurnal Pendidikan IPA Indonesia, 7(1), 54-65. https://doi.org/10.15294/jpii.v7i1.10495

Ningsih, P. R., Hidayat, A., \& Kusairi, S. (2018). Penerapan problem based learning untuk meningkatkan kemampuan berpikir kritis dan hasil belajar siswa kelas III. Jurnal Pendidikan: Teori, Penelitian, Dan Pengembagan, 3(12), 1587-1593. https://doi.org/http://dx.doi.org/10.17977/jptpp.v3i12.11799

Pamungkas, D., Mawardi, \& Astuti, S. (2019). Peningkatan Keterampilan Berpikir Kritis dan Hasil Belajar Matematika Pada Siswa Kelas 4 Melalui Penerapan Model Problem Based Learning. Jurnal Ilmiah Sekolah Dasar, 3(2), 212-219. https://doi.org/10.31004/basicedu.v3i1.98

Prasedari, L. P. E., Pudjawan, K., \& Suranata, K. (2019). Pengaruh Model Pembelajaran Problem Based Learning Berorientasi Tri Pramana Terhadap Hasil Belajar Matematika Siswa Kelas IV. Jurnal Ilmiah Kependidikan, 1(3), 50-60. https://doi.org/10.23887/jpmu.v1i2.20771

Primayanti, P. E., Suarjana, I. M., \& Astawan, I. G. (2019). Pengaruh Model Pbl Bermuatan Kearifan Lokal terhadap Sikap Sosial dan Kemampuan Berpikir Kritis Matematika Siswa Kelas V di Gugus V Kecamatan Sukasada. Thinking Skills and Creativity Journal, 1(2), 86. https://doi.org/10.23887/tscj.v1i2.20417

Pursitasari, I. D., Suhardi, E., Putra, A. P., \& Rachman, I. (2020). Enhancement of student's critical thinking skills through science context-based inquiry learning. Jurnal Pendidikan IPA Indonesia, 9(1), 97105. https://doi.org/10.15294/jpii.v9i1.21884

Rahmawati, A. (2018). Identifikasi Masalah yang Dihadapi Guru dalam Penerapan Kurikulum 2013. Indonesian Journal of Primary Education, 2(1), 114-123. https://doi.org/10.17509/ijpe.v2i1.14227

Redhana, I. W. (2013). Model pembelajaran berbasis masalah dan pertanyaan socratik untuk meningkatkan keterampilan berpikir kritis siswa. Jurnal Cakrawala Pendidikan, 3, 351-365. https://doi.org/10.21831/cp.v0i3.1136

Setyawan, I. W. P. A., Suniasih, N. W., \& Negara, I. G. A. O. (2017a). Pengaruh Quantum Teaching Berbasis Catur Kelas V Sd Gugus Srikandi Denpasar Timur 2016 / 2017. MIMBAR PGSD Undiksha, 2(5). http://dx.doi.org/10.23887/jjpgsd.v5i2.10762

Setyawan, I. W. P. A., Suniasih, N. W., \& Negara, I. G. A. O. (2017b). Pengaruh quantum teaching berbasis Catur Pramana terhadap kompetensi pengetahuan IPA siswa kelas V SD gugus Srikandi Denpasar Timur tahun pelajaran 2016/2017. MIMBAR PGSD Undiksha, 2(5). https://doi.org/http://dx.doi.org/10.23887/jjpgsd.v5i2.10762

Sugiyono. (2016). Metode Penelitian Kualitatif, Kuantitatif, dan R\&D. Alfabeta.

Sukma, M. C., \& Ibrahim, M. (2016). Developing materials for active learning of guided inquiry-integrated bowling campus on the topic of sense of hearing and sonar system of the living organism. Jurnal Pendidikan IPA Indonesia, 5(2), 256-260. https://doi.org/10.15294/jpii.v5i2.5981

Suryawati, E., Suzanti, F., Zulfarina, Putriana, A. R., \& Febrianti, L. (2020). The implementation of local environmental problem-based learning student worksheets to strengthen environmental literacy. Jurnal Pendidikan IPA Indonesia, 9(2), 169-178. https://doi.org/10.15294/jpii.v9i2.22892

Wibawa, B., \& Winarsih, M. (2020). Integral Calculus Learning Using Problem Based Learning Model Assisted by Hypermedia-Based E-Book. 9(2), 224-235. https://doi.org/10.23887/jpiundiksha.v9i2.23106 